organized in the same year. In spite of considerable opposition, the first fire lookout tower was placed in operation in 1918. This system has proved its value many times over and the number of towers has grown to thirty-five. Again, in 1924, New Brunswick became the first province to appoint a graduate forester as deputy minister in charge of forests. The policy was followed by Quebec fourteen years later, and by Ontario, but not until 1941. Foresters employed with the Government of New Bruns. wick and with the forest industries of the province now number over thirty and even the most casual observer can see the improvement in the forest policy of the province that has been brought about directly and indirectly by the establishment of the University of New Brunswick Forest School and its activities during the past thirty-five years.

\title{
NEW ENGLAND SECTION, SOCIETY OF AMERICAN FORESTERS
}

The annual meeting of the New England Section, Society of American Foresters was held at Springfield, Massachusetts on February 26 and 27 with C. S. Herr as chairman. Officers elected for the ensuing year were F. M. Callward, Chairman, J. D. Curtis, Vice-Chairman, and A. D. Rhodes, Secretary-Treasurer. L. A. Nix was elected Eastern Canadian representative on the executive council.

The agenda of the meeting was largely in the form of reports by the various committees of the section. Some of these reports called forth lively discussion. Certain revisions of the forest practice rules which were recently published in the Forestry Chronicle were suggested. The advisability of extended discussion before final adoption of these rules was generally ad. mitted. A discussion on the need for greater vigilance and increased preparations to combat fires of incendiary origin closely paralleled discussions at recent meetings of the Maritime Section, Canadian Society of Forest Engineers and of the new Brunswick Section, Canadian Forestry Association.

A considerable argument developed over the Omnibus Bill which proposes public regulation of private cutting and over the report of the Committee on Policy. The latter report is to be published in the Journal of Forestry.

The report of the Committee on Forest Insects and Diseases again illustrated the common problems of New England and adjacent regions of Canada. The forest insect situation in the Maritimes was presented by $A$. S. West, Jr., of the University of New Brunswick.

The makers of the Indian Fire Pump donated three pumps as door prizes at the annual banquet. This practice was an innovation to those foresters who have basked in the hospitality of the "pump room" while attending meetings of the Canadian Society of Forest Engineers.

\section{FRASER COMPANIES LIMITED, PROMOTE EDUCATION IN WOODLOT MANAGEMENT}

E. L. Howie, in a recent letter, outlined work which has been done in Madawaska County, N.B., to encourage better management of farm 